DOI: $10.17516 / 1998-2836-0185$

УДК $547.655+547.51$

\title{
Synthesis of 4-(1-Adamantyl)-1-Naphthol and 4-(1-Adamantyl)-1-Methoxynaphthalene
}

\author{
Alexander A. Kondrasenko ${ }^{\mathrm{a}, \mathrm{b}}$, \\ Ivan V. Peterson*a and Anatoly I. Rubaylo ${ }^{\mathrm{a}, \mathrm{c}}$ \\ anstitute of Chemistry and Chemical Technology SB RAS \\ FRC "Krasnoyarsk Science Center SB RAS" \\ Krasnoyarsk, Russian Federation \\ ${ }^{b}$ Kirensky Institute of Physics SB RAS \\ Krasnoyarsk, Russian Federation \\ 'Siberian Federal University \\ Krasnoyarsk, Russian Federation
}

Received 01.06.2020, received in revised form 07.07.2020, accepted 12.08.2020

Abstract. Adamantylation of 1-napthol and 1-methoxynaphthol in the mixture of phosphoric and glacial acetic acids leads to the formation of 2- and 4-substituted products. Formed products are less involved into the further oxidative transformations in used conditions.

Keywords: 1-naphthol, adamantan-1-ol, alkylation, trifluoroacetic acid, phosphoric acid.

Citation: Kondrasenko A.A., Peterson I.V., Rubaylo A.I. Synthesis of 4-(1-adamantyl)-1-naphthol and 4-(1-adamantyl)-1methoxynaphthalene, J. Sib. Fed. Univ. Chem., 2020, 13(3), 324-329. DOI: 10.17516/1998-2836-0185

(c) Siberian Federal University. All rights reserved

This work is licensed under a Creative Commons Attribution-NonCommercial 4.0 International License (CC BY-NC 4.0).

* Corresponding author E-mail address: Ivan.Peterson.Krsk@gmail.com 


\title{
Синтез 4-(1-адамантил)-1-нафтола \\ и 4-(1-адамантил)-1-метоксинафталина
}

\author{
А.А. Кондрасенко ${ }^{\mathrm{a}, \boldsymbol{\sigma}}$, \\ И.В. Петерсон ${ }^{\mathrm{a}}$, А.И. Рубайло, \\ ${ }^{a}$ Институт химии и химической технологии \\ ФИЦ «Красноярский научный иентр СО РАН» \\ Российская Федераиия, Красноярск \\ ${ }^{6}$ Институт физики им. Л.В. Киренского \\ Российская Федераиия, Красноярск \\ ${ }^{8}$ Сибирский федеральный университет \\ Российская Федераџия, Красноярск
}

Аннотация. Реакция адамантилирования 1-нафтола и 1-метоксинафтола в смеси фосфорной и ледяной уксусной кислот приводит к образованию 2- и 4-адамантил-замещенных продуктов. В использованных условиях реакции образующиеся продукты менее вовлечены в дальнейшие окислительные превращения.

Ключевые слова: 1-нафтол, 1-адамантанол, алкилирование, трифторуксусная кислота, фосфорная кислота.

Цитирование: Кондрасенко, А.А. Синтез 4-(1-адамантил)-1-нафтола и 4-(1-адамантил)-1-метоксинафталина / А.А. Кондрасенко, И.В. Петерсон, А.И. Рубайло // Журн. Сиб. федер. ун-та. Химия, 2020. 13(3). С. 324-329. DOI: $10.17516 / 1998-2836-0185$

\section{Introduction}

Electrophilic alkylation of aromatic compounds remains the area of study for more than a century. This type of reactions in the presence of acid catalysts currently seems well established [1,3]. Naphthols in reactionsof such type often pose as problematic nucleophiles which readily dimerize or transform into quinone type compounds after concurrent oxidation [2].

Combined aromatic core and adamantane moiety often pose as structural elements in promising antivirus compounds or functional materials [4-6]. Earlier we have reported the method of preparation of 2-(adamant-1-yl)-1-hydroxynaphthalene in reaction of 1-naphthol and 1-adamantanol in the mixture of chloroform and trifluoroacetic acid [7]. The reaction of 1-naphthol and 1-adamantanol in trifluoroacetic acid yield 3,7-di-(adamant-1-yl)-1-hydroxynaphthalene [7, 8]. The same pattern of substitution was found in the reaction of 1-methoxynaphthalene which in the said conditions yield 3,7-di-(adamant-1-yl)-1-methoxynaphthalene as a product [8].

There are surprisingly less examples of introducing adamantyl or tert-butyl group at the $\mathrm{C}(4)$ position of 1-naphthol. In the one successful attempt 4-tert-butyl-1-hydroxynaphthalene was synthesizedwith the aid of Lewis acid catalysts [9]. Authors noted that isolation of the product demanded operating under inert atmosphere due to rapid decomposition of product. 
Georghiou et al. have investigated tert-butylation of 1-naphthol in the presence of various Bronsted and Lewis acids. They found that the only products in the reactions employing Hirashima and Miyata's conditions were 3-tert-butyl-1-napthol, 7-tert-butyl-1-napthol and 3,7-di-tert-butyl-1-napthol [9, 10]. In other attempts 2-tert-butyl-1,4-naphthoquinone and 2-tert-butyl-1-naphthol were isolated from reaction mixtures $[10,11]$. In all cases there were no traces of 4-tert-butylated products.

In the following experiments we have employed a mixture of phosphoric and glacial acetic acids for the introduction of 1-adamantyl into some 1-naphthol homologues. Earlier this mixture proved to be efficient catalyst for alkylationin comparatively mild conditions $[12,13]$.

\section{Results and discussion}

In our study we have found that the reaction of 1-naphthol and 1-adamantanol in the mixture of phosphoric and glacial acetic acid yield 2-(1-adamantyl)-1-naphthol (Ia) and 4-(1-adamantyl)-1naphthol (Ib). The ratio of the products was found to be 1:1 by ${ }^{1} \mathrm{H}$ NMR of raw material. This ratio did not change if the reaction made with the excess of either 1-naphthol or 1-adamantanol.

The reaction of the 1-methoxynaphthalene with 1-adamantanol in this conditions yield 4-(1-adamantyl)-1-methoxynaphthalene (IIa). The general synthesis scheme is presented on Fig. 1.

The molecular structures of the compounds Ia, Ib, IIa was confirmed with the aid of the NMR spectroscopic methods. Previously, we have studied peculiarities of NMR spectra of hydroxynaphthalenes with mono- and di- adamantyl substituents [14].

The ${ }^{13} \mathrm{C}$ NMR spectra of the compounds substituted at fourth position include characteristic peaks at the $107.78 \mathrm{ppm}$ (Ib) and $103.07 \mathrm{ppm}$ (IIa). 2D NMR correlations on HMBC spectra were used to assign quaternary carbon atoms at the $\mathrm{C}(4)$ positions and quaternary bridgehead atom of 1-adamantyl group (138.90 and 37.93 ppm in structure Ib, 138.13 and 37.85 ppm in structure IIa).

It is also notable that acquired compound Ib is less stable than Ia on silica gel. On the other side IIa did not decompose on the chromatographic column.

Our results show that adamantyl fragment could be introduced at the either $\mathrm{C}(2)$ or $\mathrm{C}(4)$ if the mixture of phosphoric and glacial acetic acids used as reaction medium. The products of reaction are in accord with relative preference of activated positions in naphthalene rings towards electrophilic substitution. The reaction with methoxynaphthalene leads to 4 -substituted compound as the only product. Such selectivity could be connected with the combined steric effect of nearest peri-hydrogen and methoxyl group. This effect inhibit formation of the 2-adamantyl-1-methoxynaphthol.

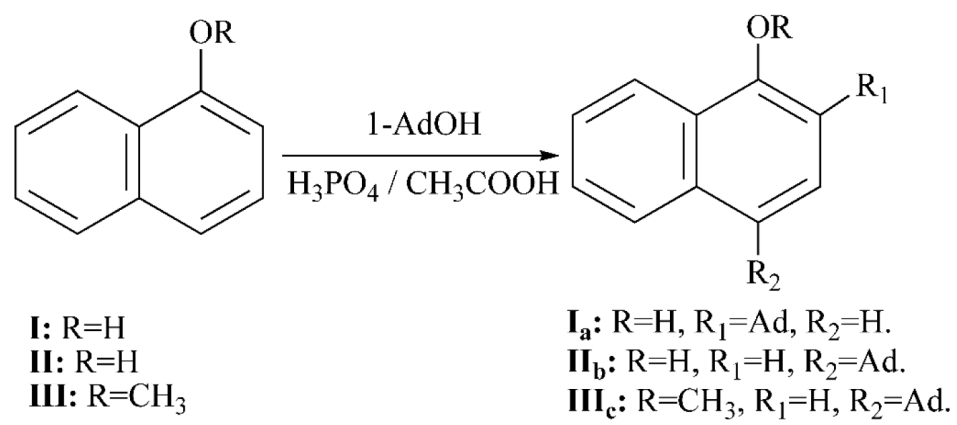

Fig. 1. Synthesis of adamantylated products $\mathbf{I}_{\mathbf{a}}, \mathbf{I I}_{\mathbf{b}}$ and $\mathbf{I I I}_{\mathbf{c}}$ 
Similar results were described by Brady et al. for the 2-naphthol who found that 1-tert-butyl-2napthol was inaccessible in the Friedel-Crafts conditions [17].

\section{Experimental section}

A general experimental procedure is as follows: substituted naphthalene $(1.0 \mathrm{mmol})$ and adamantan-1-ol (1.0 mmol, $0.152 \mathrm{~g}$ ) were dissolved in a mixture of acetic acid ( $3 \mathrm{ml}, 80 \%)$ and $\mathrm{H}_{3} \mathrm{PO}_{4}$ $(7.5 \mathrm{ml}, 85 \%)$ and stood at $30-35{ }^{\circ} \mathrm{C}$ in a closed vessel. After 24 hours reaction mixture was diluted with cold water. Solid precipitate was filtered, washed with water, and dried. The crude product was purified by column chromatography (3:1 $n$-hexane/acetone). The course of reaction and the purity of final products was controlled by TLC.

The ${ }^{1} \mathrm{H},{ }^{13} \mathrm{C}$ and 2D HSQC, HMBC NMR spectra were recorded on the Bruker Avance III spectrometer $\left(600 \mathrm{MHz}{ }^{1} \mathrm{H}, 150 \mathrm{MHz}{ }^{13} \mathrm{C}\right)$. Chemical shifts are given in the parts per million and $\mathrm{J}$ coupling constants are in Hertz units.

\section{2-(1-Adamantyl)-1-naphthol (Ia) and 4-(1-adamantyl)-1-naphthol (Ib).}

Acquired $0.950 \mathrm{~g}$ of raw products $(86 \%)$. Raw reaction products $(200 \mathrm{mg})$ were purified by column chromatography.Yield Ia $0.084 \mathrm{~g}$ (42\%). TLC Rf=0.4 (3:1 $n$-hexane/acetone), M.P. $207-208{ }^{\circ} \mathrm{C}$ (lit. 209.2-209.6 $\left.{ }^{\circ} \mathrm{C}[3]\right)$.

${ }^{1} \mathrm{H}$ NMR $\left(\mathrm{CDCl}_{3}\right): 1.85$ (m, 6H); 2.17 (m, 3H); 2.26 (m, 6H); 5.09 (br.s., 1H); 7.44 (m, 1H); 7.45 (m, 2H); 7.79 (m, 1H, J=8.5); 8.03 (m, 1H, J=8.5). ${ }^{13} \mathrm{C} \mathrm{NMR}\left(\mathrm{CDCl}_{3}\right)$ : 29.1 (Ad-CH(3,5,7)); 36.7 (Ad$\left.\mathrm{CH}_{2}(4,6,10)\right) ; 37.0$ (Ad-C(1)); $41.3\left(\right.$ Ad- $\left.\mathrm{CH}_{2}(2,8,9)\right) ; 119.9$ (Ar-C(3)); 120.2; 125.0; 125.2; 125.4; 129.5; 132.9 (Ar-C(2)); 149.1 (Ar-C(1)).

Yield Ib $0.058 \mathrm{~g}$ (29\%). TLC Rf=0.5 (3:1 $n$-hexane/acetone), M.P. $202-203{ }^{\circ} \mathrm{C}$.

${ }^{1} \mathrm{H}$ NMR $\left(\mathrm{CDCl}_{3}\right): 1.89(\mathrm{~m}, 6 \mathrm{H}) ; 2.20(\mathrm{~m}, 3 \mathrm{H}) ; 2.31(\mathrm{~m}, 6 \mathrm{H}) ; 5.55$ (br.s., $\left.1 \mathrm{H}\right) ; 6.78(\mathrm{~d}$, $1 \mathrm{H}, \mathrm{J}=8.1) ; 7.28(\mathrm{~d}, 1 \mathrm{H}, \mathrm{J}=8.1) ; 7.47(\mathrm{~d}, 1 \mathrm{H}) ; 7.50(\mathrm{~d}, 1 \mathrm{H}) ; 8.30(\mathrm{~d}, 1 \mathrm{H}, \mathrm{J}=8.3) ; 8.66(\mathrm{~d}, 1 \mathrm{H}$, $\mathrm{J}=8.5) .{ }^{13} \mathrm{C} \mathrm{NMR}\left(\mathrm{CDCl}_{3}\right)$ : $29.4(\mathrm{Ad}-\mathrm{CH}(3,5,7)) ; 37.2\left(\mathrm{Ad}-\mathrm{CH}_{2}(2,8,9)\right) ; 37.9$ (Ad-C(1)); 42.9 (Ad$\left.\mathrm{CH}_{2}(4,6,10)\right) ; 107.8$ (Ar-C(2)); 120.8; 122.9; 123.2; 125.7; 126.5; 132.5; 138.9 (Ar-C(4)); 149.9 (Ar-C(1)).

Found, \%: C, 86.29; H, 7.95. $\mathrm{C}_{20} \mathrm{H}_{22} \mathrm{O}$. Calculated, \%: C, 86.33; H, 7.91.

\section{4-(1-adamantyl)-1-methoxynaphthalene (IIa).}

Yield 0.176g (55\%). TLC Rf=0.9 (3:1 n-hexane/acetone), M.P. $183-184{ }^{\circ} \mathrm{C}$.

${ }^{1} \mathrm{H} \mathrm{NMR}\left(\mathrm{CDCl}_{3}\right): 1.90$ (m, 6H); 2.21 (m, 3H); 2.32 (m, 6H); 4.00 (s, 3H); 6.78 (d, 1H, J=8.3); 7.37 $(\mathrm{d}, 1 \mathrm{H}, \mathrm{J}=8.3) ; 7.46$ (ddd, $1 \mathrm{H}, \mathrm{J}=8.3,1.6) ; 7.50(\mathrm{ddd}, 1 \mathrm{H}, \mathrm{J}=8.2,6.7,1.2) ; 8.39$ (dd, $1 \mathrm{H}, \mathrm{J}=8.5,1.6) ; 8.65$ (dd, 1H, J=8.7). ${ }^{13} \mathrm{C}$ NMR $\left(\mathrm{CDCl}_{3}\right)$ : 29.4 (Ad-CH(3,5,7)); $37.2\left(\mathrm{Ad}^{-\mathrm{CH}_{2}}(4,6,10)\right) ; 37.9$ (Ad-C(1)); 42.9 $\left(\operatorname{Ad}-\mathrm{CH}_{2}(2,8,9)\right) ; 55.4\left(\mathrm{OCH}_{3}\right) ; 103.1(\mathrm{Ar}-\mathrm{C}(2)) ; 123.1 ; 123.9 ; 124.8 ; 126.3 ; 126.9 ; 132.2 ; 138.1$ (Ar-C(4)); 153.9 (Ar-C(1)).

Found, \%: C, 86.20; H, 8.31. $\mathrm{C}_{21} \mathrm{H}_{24} \mathrm{O}$. Calculated, \%: C, 86.26; H, 8.27.

\section{Conclusion}

It is known that alkylated electron rich aromatic compounds have oxidation potentials lower than starting material [10]. Also, this property is further amplified with the steric strain induced by bulky substituent [11]. The ability to easily oxidize becomes the obstacle for synthesis and isolation of the desired products. 
Proposed adamantylation of 1-napthol in the mixture of phosphoric and glacial acetic acids leads to the formation of the desired 2- and 4-substituted products. Under the used reaction conditions products are less involved into the further oxidative transformations. This is in contrast to the results of reactions employing conventional catalysts $[4,5]$.

\section{Acknowledgements}

This work was conducted within the framework of the budget project (AAAA-A17-117021310221-7) for Institute of Chemistry and Chemical Technology SB RAS using the equipment of Krasnoyarsk Regional Research Equipment Centre of SB RAS.

\section{References}

1. Smith M.B. Organic Chemistry. 4th ed. CRC Press, 2016. 1083 p.

2. Naredla R.R., Klumpp D.A. Contemporary Carbocation Chemistry: Applications in Organic Synthesis Chem. Rev. 2013. Vol. 113(9), P. 6905-6948.

3. Side Reactions in Organic Synthesis II. Under ed. Zaragoza Dorwald F. Weinheim, Germany: Wiley, 2014. 1-295 p.

4. Plewe M.B. et al. Discovery of Adamantane Carboxamides as Ebola Virus Cell Entry and Glycoprotein Inhibitors ACS Med. Chem. Lett. 2020. Vol. 11(6), P. 1160-1167.

5. Tominaga M., Katagiri K., Azumaya I. Pseudopolymorph and Charge-Transfer Co-Crystal of Disubstituted Adamantane containing Dimethoxyphenol Moieties. Cryst. Growth Des. 2009. Vol. 9(8), P. 3692-3696.

6. Tominaga M., Masu H., Azumaya I. Hydrogen-Bonding Networks of Adamantane-Based Bisphenol Molecules: Toward the Preparation of Molecular Crystals with Channels. Cryst. Growth Des. 2011. Vol. 11(2), P. 542-546.

7. Sokolenko V.A., Svirskaya N.M., Pavlenko N.I. Adamantylation of 1-and 2-naphthols with 1-adamantanol in trifluoroacetic acid. Russ. J. Org. Chem. 2007. Vol. 43(5), P. 782-783.

8. Stepakov A.V., Molchanov A.P., Kostikov R.R. Alkylation of aromatic compounds with adamantan-1-olRuss. J. Org. Chem. 2007. Vol. 43(4), P. 538-543.

9. Hirashima T., Miyata T., Yuki Gosei Kagaku Kyokaishi 1976. Vol. 34(6), P. 434-434 [in japan].

10. Georghiou P. E., Ashram M. Regioselectivity in the Friedel-Crafts tert-Butylation of 1-Naphthol. J. Org. Chem. 1995. Vol. 60(9), P. 2909-2911.

11. Hirashima T., Miyata T. Yuki Gosei Kagaku Kyokaishi 1976. Vol. 34(6), P. 433-433 [in japan].

12. Patent 2881219 US. Thompson R.B. Alkylation of arylols. Publ. Date 07.04.1959.

13. Peterson I.V., Svirskaya N.M., Kondrasenko A.A., Rubaylo A.I. 1-Adamantanol Alkylation of 1,8- and 1,3- Dihydroxynaphthalenes. Journal of Siberian Federal University. Chemistry 2016. Vol. 9, P. 134-139.

14. Peterson I.V., Svirskaya N.M., Kondrasenko A.A., Rubaylo A.I. ${ }^{1} \mathrm{H}$ and ${ }^{13} \mathrm{C}$ NMR spectral assignments of novel adamantyl and di-adamantyl derivatives of 1,2-; 1,8-; 2,3-; 2,6- and 2,7-dihydroxynaphthalenes. Magn. Reson. Chem, 2016. Vol. 54, P. 912-915.

15. Brady P.A., Carnduff J., Leppard D.G. The Friedel-Crafts $t$-butylation of 2-naphthol. Tetrahedron Lett. 1972. Vol. 13, P. 4183-4186. 
16. Fieser, L.F. The potentials of some unstable oxidation-reduction systems. J. Am. Chem. Soc.1930. Vol. 52, P. 5204-5241.

17. Brady P.A., Carnduff J. Autoxidation of strained 1-alkyl-2-naphthols: steric acceleration in a radical chain reaction. J.S.C. Chem. Commun.1974. Vol. 20, P. 816-817. 